\title{
Genetic Improvement of Black Locust: A Prime Agroforestry Species ${ }^{1}$
}

\author{
by James W. Hanover, Tesfai Mebrathu, and Paul Bloese ${ }^{2}$
}

\begin{abstract}
Black locust (Robinia pseudoacacia L.) is one of the fastest growing trees in North America, it fixes atmospheric nitrogen, it has a very dense, attractive wood, and possesses many other attributes desirable for an agroforestry species. Results of research on its genetic improvement show a large amount of genetic variation among and within families for growth, form, thorn length and other important traits. There is virtually no variation associated with geographic regions. A detailed plan for the genetic improvement and mass propagation of superior trees, through seed, root cuttings, and tissue culture is outlined.
\end{abstract}

\section{Introduction}

Among the many problems facing our world are needs for: (1) new renewable energy sources; (2) methods to reclaim abused land and prevent soil erosion; and (3) revegetation of unproductive sites for food and fibre. These problems are not unique to the lesser developed countries; hence agroforestry systems which address these problems are being studied in more developed countries as well. Most agroforestry systems involve intimate combinations of trees and either/both agricultural crops or animals. However, at Michigan State University (MSU) we are expanding the concept to include the culture of trees for marginal agricultural land, for use as fuel, animal feed, or feedstock for chemical production, for a human food source such as leaf protein, and so on (Hanover 1980). Our goal is to develop both genetically and culturally, rapid growing, short rotation, multipurpose tree species for use by farmers and other landowners in Michigan (Barrett et al. 1988, Miller et al. 1987). Towards this end we have chosen to concentrate much of our efforts on black locust (Robinia pseudoacacia L.) for a number of reasons which are elaborated below. In addition, we present procedures and data for the genetic improvement of black locust in order to further enhance its utility as both a conventional and agroforestry species.

\section{Attributes of Black Locust}

Although it is one of the most commonly planted trees in the world, amounting to over three and a quarter million hectares (Keresztesi 1988a), black locust is only beginning to receive close attention by foresters and researchers in its native habitat, the eastern United States. The species has become naturalized well outside its original range and now grows in all 48 contiguous states. This testifies to the wide adaptability of the species and its popularity throughout temperate regions of the world.

\footnotetext{
${ }^{1}$ Paper submitted for inclusion in Proceedings of the First Conference on Agroforestry in North America, held August 1989, Guelph, Ontario, Canada. ${ }^{2}$ Department of Forestry, Michigan State University, East Lansing, MI 48824 , U.S.A.
}

\section{Résumé}

Le robinier noir (Robinia psudoacatia L.) compte parmi les essences dont la croissance est la plus rapide en Amérique du Nord. En plus de fixer l'azote libre, cette essence possède un bois très dense et attrayant ainsi que plusieurs autres propriétés désirables aux fins d'agroforesterie. Les résultats de la recherche sur l'amélioration génétique de cette essence révèle une variation génétique importante parmi les familles de cette essence en ce qui a trait à la croissance, la forme, la longueur des épines et d'autres caractéristiques importantes. Il n'y a pas de variation attribuable à la distribution géographique. Ce texte présente un plan détaillé pour l'amélioration génétique et la propagation d'arbres supérieurs au moyen de graines, de boutures de racines et de cultures de tissus.

Black locust is one of the most productive tree species in North America in terms of growth rate and biomass production (Miller et al. 1987). It grows as much as 2 to 2.5 meters from seed during its first year and sustains rapid growth through the juvenile and mature phases of a rotation. Its rapid growth rate is largely due to very high net photosynthetic rate (Mebrahtu 1989). On good sites it will yield more than $14 \mathrm{~m}^{3}$ per hectare per year over a 40 -year rotation with only moderately intensive management techniques (Keresztesi 1988a). Intensive cultural practices will substantially increase these yields. The species has nodulated roots and fixes atmosphere nitrogen eliminating a need for nitrogen fertilization. In a study done to determine the effects of nitrogen fertilization on growth of black locust, the growth of non-fertilized plants was not significantly different

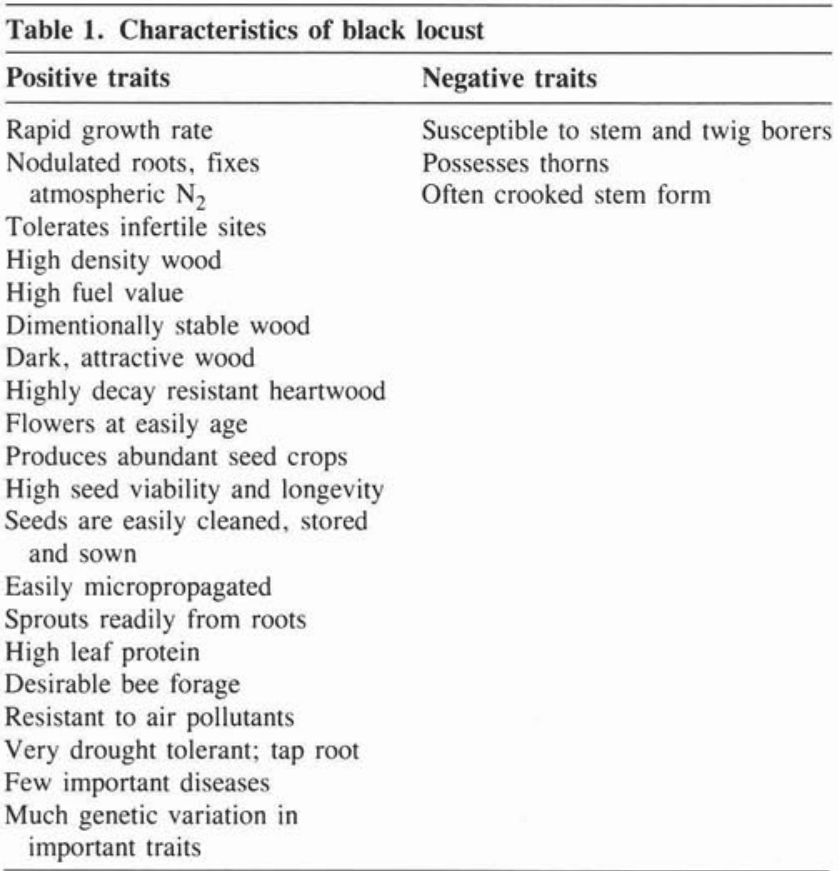




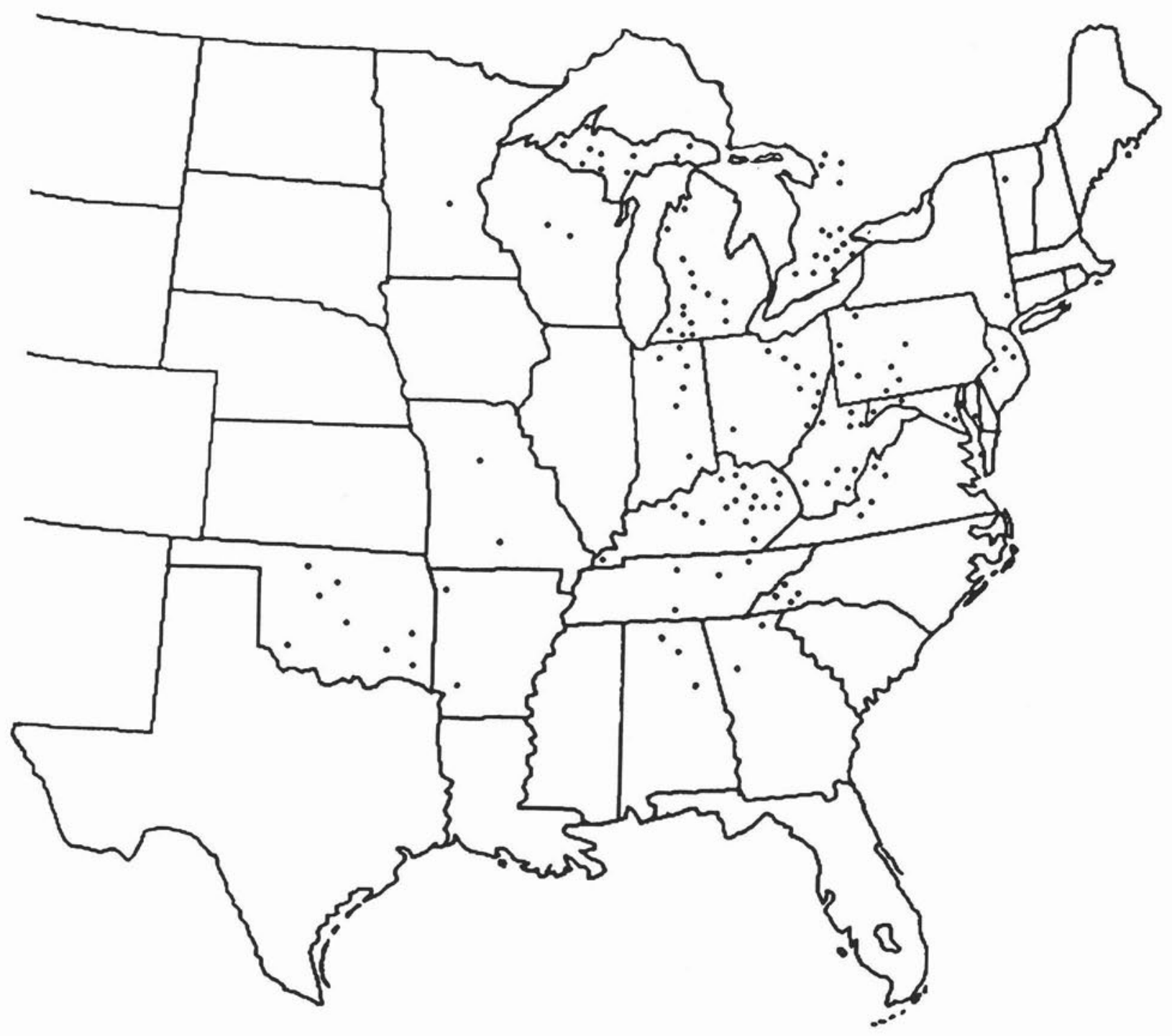

Figure 1. Location of stands from which seed collections were made from native or naturalized black locust trees.

from those fertilized with $440 \mathrm{ppm}$ of elemental nitrogen once every two weeks for 15 weeks (Mebrahtu 1989). It tolerates low fertility sites, drought and both high and low temperatures.

The wood is very dense $\left(680 \mathrm{~kg} / \mathrm{m}^{3}\right)$ and has a high caloric value $(3500 \mathrm{kcal} / \mathrm{kg}$ at $15 \%$ moisture $)$. It is the strongest wood of the commercial species in North America, yet is also among the most dimensionally stable upon drying. The wood is dark and attractive and extremely resistant to wood decay organisms due to its unique heartwood chemistry (Smith et al. 1989a, 1989b). It is suitable for processing into almost any product make from wood.

Black locust flowers as early as three years of age making possible rapid genetic advances through breeding. For this reason, it can also be used as a model plant in forest genetics research. Seed crops are abundant and quite consistent year to year. The seed is very easy to store, process and germinate. The species is also easily regenerated or propagated from root sprouts (Keresztesi 1988b) and tissue culture (Chalupa 1983, Davis and Keathley 1987). It has a leaf protein content higher than alfalfa (Baertsche et al. 1986); it is excellent bee forage and appears to be resistant to air pollutants (Walker 1984) and damaging diseases.
There are several undesirable characteristics of the species; the stem form is often crooked, it has thorns mainly in juvenile tissues, and in certain areas it is attacked by a stem boring insect, Megacyllene robinae, and/or a twig boring insect, Ecdytolopha insiticiana, both of which cause varying degrees of damage from slight to severe. A leaf mining insect, Parectopa robinella, may also cause some damage appearing as blotches on the leaf.

Thus, black locust is a species which possesses a wide range of highly desirable traits for agroforestry and many other purposes along with a few traits that limit its usefulness (Table 1). Fortunately, the species has exhibited a large amount of genetic variation in the few trials underway to date (Keresztesi 1983, Barrett et al. 1988, Mebrahtu and Hanover 1989, Surles et al. 1989).

In spite of its several hundred years in cultivation there have been virtually no systematic genetic tests or breeding efforts for black locust until very recently. For this reason there is a strong likelihood that even the few negative characteristics of black locust may soon be minimized or eliminated through genetic manipulation. The program at MSU has been working towards this end and early results are promising. 
BLACK LOCUST BREEDING PROGRAM

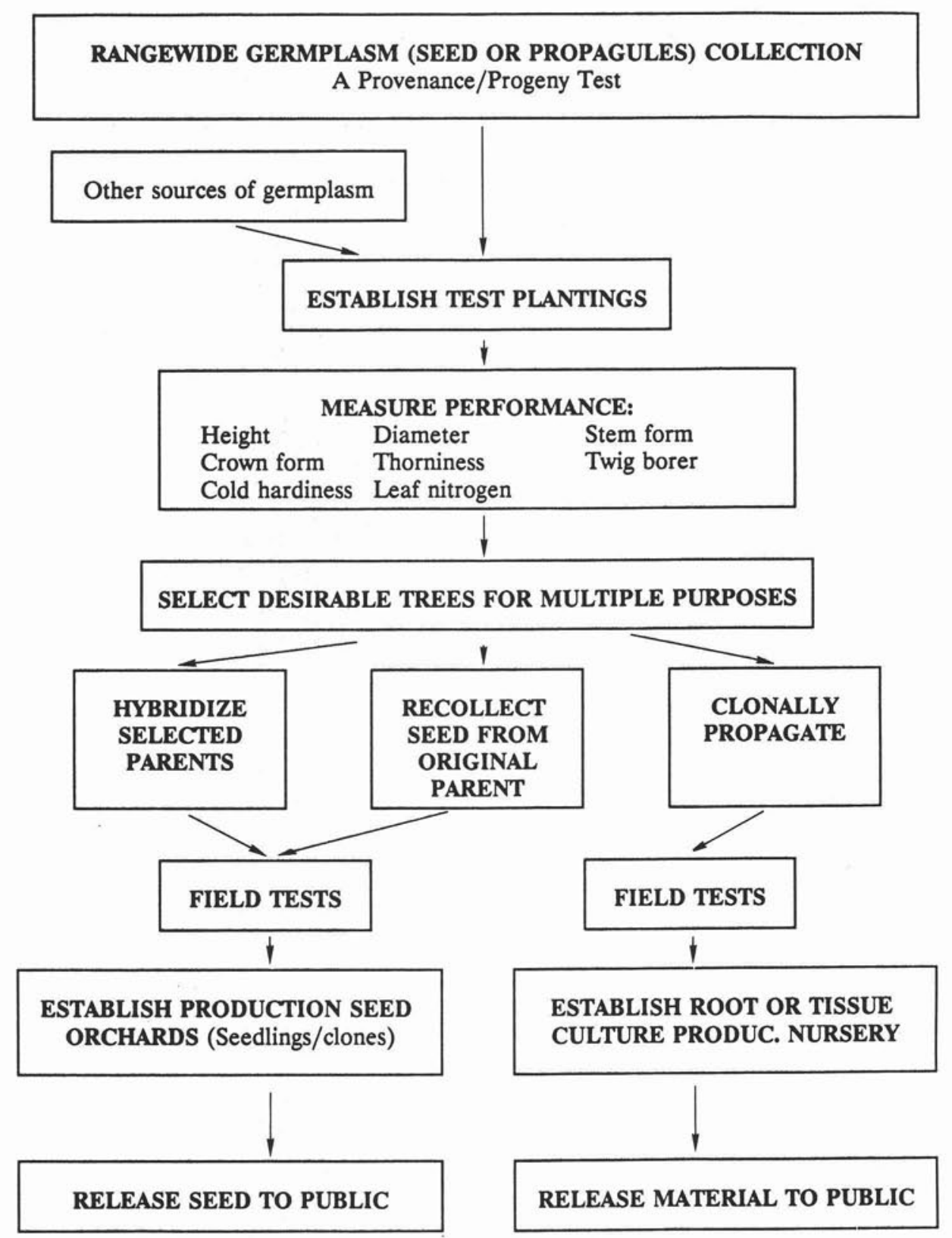

Figure 2. Procedures used in the Michigan State University black locust breeding program.

\section{Procedures for Improving Black Locust}

The Hungarian experience gives encouragement to the belief that straight stem black locust can be achieved through cultural practices, such as planting at closer spacings. There is also evidence that genetically straight-stemmed varieties can be bred (Keresztesi 1988a). No information is available about resistance to borer insects or the existence of thornless black locust. With this dearth of genetic information about the species we began an extensive genetic improvement program in 1984.

The MSU black locust breeding program began in 1984 with an extensive sampling of the expanded eastern United States range of the species (Figures 1 and 2). Because seeds were collected from individual trees rather than bulked together the test is also a half-sib progeny test. The purposes of this test are to reveal genetic versus environmental control over variation in traits, to determine the types and degree of genetic control, and to provide the opportunity for selecting outstanding parents for cloning and advanced generation breeding. Trees in the provenance/progeny test established at two sites near East Lansing and Kalamazoo, Michigan, were measured at one-, two- and five-years of age for all important traits (Figure 2). A very small proportion, less than $1 / 2 \%$ or about 40 of the most desirable trees were selected for further study. These selected trees are used to obtain root or stem material to propagate vegetatively or 
Table 2. Summary of variability for height, dieback and number of leaders of black locust, determined at the end of one growing season in the field

\begin{tabular}{|c|c|c|c|c|c|}
\hline \multirow[b]{2}{*}{ Trait } & \multicolumn{3}{|c|}{ Half-sib family averages } & \multicolumn{2}{|c|}{ Individual-tree extremes } \\
\hline & maximum & mean & minimum & maximum & minimum \\
\hline Height (m) & 2.07 & 1.28 & 0.67 & 2.90 & 0.34 \\
\hline $\begin{array}{l}\text { Winter } \\
\text { dieback } \\
(\mathrm{cm})\end{array}$ & 17.3 & 6.6 & 0.0 & 109.0 & 0.0 \\
\hline $\begin{array}{c}\text { Number of } \\
\text { leaders }\end{array}$ & 4.5 & 2.3 & 1.0 & 9.0 & 1.0 \\
\hline
\end{tabular}

to obtain seed, either open pollinated or through controlled hybridization. Seedlings from both types of propagation are then planted in replicated field tests at several sites or in seed orchards. With these procedures the first genetically improved starting materials will be released to nurserymen in 1991.

Because the improvement process is a cyclic and continuing one we expect genetic gains in an ongoing breeding program to increase further with time. The most rapid method for capturing genetic gains is through clonal propagation techniques. Tissue culture, root propagation, and greenwood cuttings are all feasible methods for cloning black locust. We are currently evaluating the economics of each method for mass production of seedlings.

\section{Results of Genetic Improvement of Black Locust}

The results of measurements and analyses of black locust progenies after one year in plantations have been very encouraging (Mebrahtu and Hanover 1989). There is significant genetic variation in each of the traits analyzed at each plantation site (Tables 2 and 3 ). In addition, the narrow-sense heritability of each trait is quite high whether computed on a family mean or individual tree basis (Table 3 ). Although heritability estimates greater than 1 are conceptually impossible, this phenomenon is sometimes encountered in statistical analysis of juvenile trees (Adams and Jolly 1977, Hicks et al. 1977, Rick 1984) and may have resulted from closer relatedness than the half-sib relationship assumed. These high heritability values contribute to relatively high predicted genetic gain calculations from selection in black locust (Table 4). From these data we conclude that the genetic improvement of black locust is not only feasible, but should be highly successful if the best individuals in the best families are used either through sexual (seed orchards) or clonal (tissue culture or root propagules) methods of mass propagation.

From the standpoint of genetic improvement of black locust two other results from our tests are very important. First, there is notable consistency in rank performance of better families at the two test sites, measured at age five years in the plantations, which may obviate the need to breed for specific sites (Table 5). However, clonal tests now underway will provide more definitive results in this regard. Second, there appears to be no geographic variation in black locust for the traits we have measured. Hence, the genetic variation resides predominately in families and individuals within families and not in regions or local races. Thus, for selection and breeding purposes the species can be considered as one large breeding population which is the basis for the strategy described in Figure 2.

So far our selection efforts with black locust have concentrated on maximizing biomass and stem quality traits. These traits will probably be of primary importance in using black locust for several agroforestry systems. It is also possible that other traits such as competitive ability, leaf nitrogen content, and regrowth potential after clipping will be selected for once we incorporate the species into animal feeding systems (Barrett et al. 1988) or other agroforestry strategies.

Table 3. F-values for among family differences and heritabilities with their standard deviations $(\hat{\sigma})^{1}$

\begin{tabular}{|c|c|c|c|c|c|c|c|}
\hline Trait & Site & Height & $\begin{array}{c}\text { Winter } \\
\text { dieback }\end{array}$ & $\begin{array}{c}\text { Number } \\
\text { of } \\
\text { leaders }\end{array}$ & $\begin{array}{c}\text { Length } \\
\text { of } \\
\text { thorns }\end{array}$ & $\begin{array}{l}\text { Bud- } \\
\text { break }\end{array}$ & $\begin{array}{l}\text { Leaf } \\
\text { initia- } \\
\text { tion }\end{array}$ \\
\hline \multirow{3}{*}{$\begin{array}{l}\text { F-Value } \\
\text { for among } \\
\text { family } \\
\text { difference }\end{array}$} & Kellogg & $1.53 * *$ & $0.95 \mathrm{NS}$ & $1.17 * *$ & $1.92 * *$ & $1.36 * *$ & $1.73 * *$ \\
\hline & E. Lansing & $1.90 * *$ & $1.6 * *$ & $1.31 * *$ & $2.65 * *$ & $1.48 * *$ & $1.57 * *$ \\
\hline & Combined & $2.23 * *$ & $1.24 * *$ & $1.77 * *$ & $3.18 * *$ & $3.57 * *$ & $4.57 * *$ \\
\hline \multirow[t]{4}{*}{ Individual tree } & & \multicolumn{6}{|c|}{- Heritability $\left(h^{2}{ }_{\mathrm{i}}\right)$} \\
\hline & Kellogg & $\begin{array}{l}0.46 \pm \\
0.027\end{array}$ & - & $\begin{array}{l}0.17 \pm \\
0.023\end{array}$ & $\begin{array}{l}0.74 \pm \\
0.03\end{array}$ & $\begin{array}{l}0.62 \pm \\
0.064\end{array}$ & $\begin{array}{l}1.07 \pm \\
0.065\end{array}$ \\
\hline & E. Lansing & $\begin{array}{l}0.74 \pm \\
0.03\end{array}$ & $\begin{array}{l}0.52 \pm \\
0.028\end{array}$ & $\begin{array}{l}0.29 \pm \\
0.025\end{array}$ & $\begin{array}{l}1.16 \pm \\
0.032\end{array}$ & $\begin{array}{l}0.55 \pm \\
0.047\end{array}$ & $\begin{array}{l}0.64 \pm \\
0.048\end{array}$ \\
\hline & Combined & $\begin{array}{l}0.56 \pm \\
0.019\end{array}$ & $\begin{array}{l}0.13 \pm \\
0.013\end{array}$ & $\begin{array}{l}0.31 \pm \\
0.016\end{array}$ & $\begin{array}{l}0.89 \pm \\
0.023\end{array}$ & $\begin{array}{l}0.83 \pm \\
0.038\end{array}$ & $\begin{array}{l}1.11 \pm \\
0.04\end{array}$ \\
\hline \multirow[t]{4}{*}{ Family } & & \multicolumn{6}{|c|}{ Heritability $\left(h_{\mathrm{f}}^{2}\right)$} \\
\hline & Kellogg & $\begin{array}{l}0.34 \pm \\
0.065\end{array}$ & - & $\begin{array}{l}0.15 \pm \\
0.057\end{array}$ & $\begin{array}{l}0.48 \pm \\
0.063\end{array}$ & $\begin{array}{l}0.27 \pm \\
0.092\end{array}$ & $\begin{array}{l}0.42 \pm \\
0.088\end{array}$ \\
\hline & E. Lansing & $\begin{array}{l}0.48 \pm \\
0.063\end{array}$ & $\begin{array}{l}0.38 \pm \\
0.065\end{array}$ & $\begin{array}{l}0.24 \pm \\
0.062\end{array}$ & $\begin{array}{l}0.62 \pm \\
0.055\end{array}$ & $\begin{array}{l}0.33 \pm \\
0.069\end{array}$ & $\begin{array}{l}0.36 \pm \\
0.069\end{array}$ \\
\hline & Combined & $\begin{array}{l}0.55 \pm \\
0.072\end{array}$ & $\begin{array}{l}0.22 \pm \\
0.063\end{array}$ & $\begin{array}{l}0.40 \pm \\
0.075\end{array}$ & $\begin{array}{l}0.69 \pm \\
0.060\end{array}$ & $\begin{array}{l}0.57 \pm \\
0.086\end{array}$ & $\begin{array}{l}1.11 \pm \\
0.076\end{array}$ \\
\hline
\end{tabular}

**Significant at the 5 percent and 1 percent levels, respectively; NS, not significant at the 5 percent level.

'In T. Mebrahtu and J. Hanover (1989). Heritability and expected gain estimates for traits of black locust in Michigan. Silvae Genetica 38: 125-130. 
Table 4. Predicted genetic gains (\%) from different selection schemes under different selection intensities ${ }^{1}$

\begin{tabular}{llccc}
\hline & $\begin{array}{l}\text { Type of } \\
\text { select. }\end{array}$ & Height & $\begin{array}{c}\text { Length } \\
\text { of } \\
\text { thorns }\end{array}$ & $\begin{array}{c}\text { No. } \\
\text { of } \\
\text { leaders }\end{array}$ \\
\hline Best 10 & tree & 61 & 46 & 18 \\
trees & $\begin{array}{l}\text { combin. } \\
\text { family }\end{array}$ & 47 & 46 & 18 \\
& 19 & 27 & 18 \\
\hline Best 20 & tree & 56 & 46 & 18 \\
trees & combin. & 45 & 46 & 18 \\
& family & 16 & 24 & 16 \\
\hline Best 40 & tree & 51 & 46 & 18 \\
trees & combin. & 41 & 46 & 18 \\
& family & 13 & 20 & 14 \\
\hline
\end{tabular}

${ }^{1}$ In T. Mebrahtu and J. Hanover (1989). Heritability and expected gain estimates for traits of black locust in Michigan. Silvae Genetica 38: 125-130.

Table 5. Height growth of the best $\mathbf{1 0}$ families at the end of the fifth growing season in the field

\begin{tabular}{|c|c|c|c|c|c|}
\hline $\begin{array}{l}\text { Family } \\
\text { number }\end{array}$ & Place of origin & $\begin{array}{c}\text { Family } \\
\text { mean } \\
\text { height } \\
\text { (cm) }\end{array}$ & $\begin{array}{c}\text { Rank } \\
\text { Kellogg }\end{array}$ & $\begin{array}{c}\text { Rank } \\
\text { at E. } \\
\text { Lansing }\end{array}$ & $\begin{array}{c}\text { Rank in } \\
\text { combined } \\
\text { data }\end{array}$ \\
\hline 72 & Maryland & 593 & 8 & 4 & 1 \\
\hline 201 & Pennsylvania & 588 & 9 & 7 & 2 \\
\hline 386 & Ontario & 584 & 10 & 6 & 3 \\
\hline 297 & West Virginia & 561 & 12 & 10 & 4 \\
\hline 430 & Maryland & 556 & 13 & 15 & 5 \\
\hline 269 & Ontario & 556 & 11 & 28 & 6 \\
\hline 129 & Ohio & 552 & 24 & 9 & 7 \\
\hline 431 & Maryland & 547 & 17 & 20 & 8 \\
\hline 155 & Michigan & 547 & 29 & 12 & 9 \\
\hline 309 & West Virginia & 538 & 26 & 26 & 10 \\
\hline
\end{tabular}

\section{Acknowledgment}

This research was supported in part by the Michigan State University/USDA: CSRS Eastern Hardwood Utilization Research Special Grant Program (Grant \#F88 34158-3275).

\section{References}

Adams, W.T., and R.J. Jolly. 1977. Analysis of genetic variation for height growth and survival in open-pollinated progenies of eastern white pine. Proc. Northeast For. Tree Improv. Conf. 25: 117-131.

Baertsche, S.R., M.T. Yokoyama and J.W. Hanover. 1986. Short rotation, hardwood tree biomass as potential ruminant feed-chemical composition; nylon bag ruminal degradation, and ensilement of selected species. J. Anim. Sci. 63: 2028-2043.
Barrett, R.P., T. Mebrahtu and J.W. Hanover. 1988. Black locust: a multi-purpose tree species for temperate climates. Proc. First Nat. Symp. New Crops, Oct. 1988. Indianapolis, IN.

Chalupa, V. 1983. In vitro propagation of willows (Salix spp.), European mountain-ash (Sorbus aucuparia L.) and black locust (Robinia pseudoacacia L.). Biol. Plant. 25: 305-307.

Davis, J.M. and D.E. Keathley. 1987. Differential responses to in vitro bud culture in mature Robinia pseudoacacia L. (black locust). Plant Cell Reports 6: 431-434.

Hanover, J.W. 1980. Horizons in research on primary productivity of forests. Proc. Sixth North Amer. For. Biol. Workshop, Edmonton, Alberta, Canada.

Hicks, R.R. Jr., G. Rink and B.E. Cutter. 1977. Variation and heritability of seedling height in East Texas sycamore and rich birch. Proc. Northeast For. Tree Improv. Conf. 25: 133-137.

Keresztesi, Bela. 1983. Breeding and cultivation of black locust (Robinia pseudoacacia) in Hungary. For. Ecol. and Manage. 6: 217-244.

Keresztesi, Bela. 1988a. Black locust: the tree of agriculture. Outlook on Agriculture 17: 77-85.

Keresztesi, Bela. (Ed.) 1988b. The Black Locust. Akademiai Kiado, Budapest. 197 pp.

Mebrahtu, T. 1989. Gas exchange characteristics of black locust (Robinia pseudoacacia) in relation to growth, development and environmental factors. Ph.D. dissertation, Mich. State Univ., East Lansing, Michigan.

Mebrahtu, T. and J.W. Hanover. 1989. Heritability and expected gain estimates for various traits of black locust in Michigan. Silvae Genetica 38: 125-130.

Miller, R.O., P.D. Bloese and J.W. Hanover. 1987. Black locust: a superior short-rotation, intensive culture species for biomass production in the Lake States. Proc. IGT 11th Meeting on Energy from Biomass and Wastes, March 1987, Orlando, FL. 23 pp.

Rink, G. 1984. Trends in genetic control of juvenile black walnut height growth. For. Sci. 32: 1049-1057.

Smith, A.L., C.L. Campbell, M.P. Diwakar, J.W. Hanover and R.O. Miller. 1989a. Extracts from black locust as wood preservatives: a comparison of the methanol extract with pentachlorophenol and chromated copper arsenate. Holzforshung 43: 421-423.

Smith, A.L., C.L. Campbell, D.B. Walker and J.W. Hanover. 1989b. Extracts from black locust as wood preservatives: extraction of decay resistance from black locust. Holzforschung 43: 293-296.

Surles, Scott E., J.L. Hamrick and B.C. Bongarten. 1989. Allozyme variation in black locust (Robinia pseudoacacia). Can. J. For. Res. 19: 471-479.

Walker, L.C. 1984. Trees. Prentice-Hall, New Jersey. 